\title{
Formulation and Quality Evaluation of Finger Millet Based Composite Food Products
}

\author{
Milkesa Feyera, Fikiru Dasa, Kedir Kebero \\ Food Science and Nutrition Research, Melkassa Agricultural Research Center, Adama, Ethiopia
}

Email address:

milkesafeyera4@gmail.com (M. Feyera)

\section{To cite this article:}

Milkesa Feyera, Fikiru Dasa, Kedir Kebero. Formulation and Quality Evaluation of Finger Millet Based Composite Food Products. International Journal of Nutrition and Food Sciences. Vol. 10, No. 3, 2021, pp. 59-65. doi: 10.11648/j.ijnfs.20211003.11

Received: March 4, 2021; Accepted: May 11, 2021; Published: May 20, 2021

\begin{abstract}
Nutrient compositions of most cereal based food products are inadequate to meet the nutrient requirement for all age groups. Enrichment of cereal with easily affordable legumes, root and tubers having superior nutrients are important approaches to produce nutrient dense and sensorial acceptable food products. Therefore, this study was carried out to develop nutrient dense and acceptable food products from composite flour formulated from finger millet, ground nut, orange fleshed sweet potato and soy bean flours. Accordingly, Two types of composite flours were developed. Composite flour type I consisting 65:35, 70:30, 75:25, 80:20 and 85:15 of finger millet and soybean in proportion, respectively, were formulated for injera making. Composite flour type II consisting 60:20:20:0, 70:20:10:0, 60:20:0:20 and 70:20:0:10 of finger millet, soybean, ground nut and sweet potato, respectively, were used for porridge and kita product making. The moisture, ash, protein, fat, fiber and carbohydrate contents of the formulations were ranged from 8.141 to 9.67, 1.03 to 3.17, 4.38 to $17.17,0.02$ to $15.59,2.85$ to $13.87,60.41$ to $71.57 \%$, respectively. There was a significant difference in water absorption capacity, swelling power, water solubility and oil absorption capacity among the composite flours. Sensory acceptability of Injera made from composite flour consisting of 75:25 finger millet and soyabean, respectively, were more preferred by panelists than other proportions. Sensory attributes data showed that porridge made from composite flour formulated from 60:20:20 of finger millet, soyabean and sweet potato were highly preferred by panelists in all sensory attributes. On the other hand, Sensory acceptability of kita made from composite flour formulated from 70:20:10 of finger millet, soyabean and sweet potato, respectively, achieved highest sensorial scores. Therefore, blending of finger millet with nutritious legumes, root and tubers crops would be recommended in production of nutritious and sensorially acceptable value added food products for different purposes.
\end{abstract}

Keywords: Finger Millet, Composite Flour, Proximate Composition, Injera, Porridge, Kita

\section{Introduction}

Millets have been cultivated since prehistoric times in regions of Asia and Africa, and used for food and feed. Cereal and cereal-based food products provide more than $56 \%$ of the energy and $50 \%$ of the protein consumed worldwide [6]. Nutritionally, millets are equivalent to other cereal grains [12] and has potential health benefits in management of diabetes mellitus, obesity and hyperlipidemia [33]. Even though several millet varieties are available, finger millet is often mentioned separately from other small millets as it has thrice the amount of calcium as milk which is critical for women and babies. In addition, low glycemic index and gluten free nature of finger millet grains represent as an ideal food for peoples with celiac disease and diabetes [27]. Thus, finger millet is a good source of diet for growing children, lactating women, old age people and patients [10].

In nutrition point of view, protein-energy malnutrition is still a major public health issue in developing countries and mostly associated with $50-60 \%$ of under-five mortality [13, 25]. To overcome this situation, the development of food products using composite flour has been used for decades. Protein and micro nutrient deficiencies might be high in millet growing areas of Ethiopia as millets has less protein and fat contents compared to other cereals. Thus, there is a need to enrich millet based traditional foods with other grains and tubers. Soybean flour contains about $35-45 \%$ of protein, 
on dry weight basis and therefore it is considered an excellent source of protein [30] with all essential amino acids required for proper growth and repair of damaged human tissues. Similarly, groundnuts are also leguminous crop which has substantially high protein content [35]. On the other hand, orange fleshed sweet potato contains high levels of carotenoids, particularly, hydrogen carotenoids and beta carotene (provitamin A) [22]. Sweet potato (Ipomoea batatas L.) is one of the most traditional root crops in many countries. Vitamin A deficiency is a wide spread nutritional and health problem affecting particularly children and cause illnesses, impaired growth, development, vision, and immune systems, and in severe cases results in blindness and death [28]. In addition to its nutritional value, the use of composite flours has a few advantages in terms of the saving of hard currency; promotion of high yielding, native plant species; and encourages the use of locally grown crops as flour [20, 18]. Research finding by [24] revealed that the experience gained in the use of composite flours has clearly demonstrated for reasons of both product technology and consumer acceptance. The improvement of local food staples and utilization of locally produced staple crops in the development of high energy foods rich in micronutrients has been a subject of research over the years to meet the protein and energy need of vulnerable populations [25]. This has shown high economic advantage when composite flour made from cereals, tubers and legumes are used to develop such food products.

Value addition and improving health benefits of millets by combining with other grains and tubers and by applying advanced technologies for their processing and preservation opens new avenues for the product diversification [32]. In Ethiopia, millet is utilizing in the form of injera, unfermented porridge, bread, kita, and local beverages like farso/tella and areki. Injera is a fermented, sour bread consumed as a staple food in Ethiopia and other neighboring countries. Porridge is a major weaning food particularly in developing countries and is a food-based intervention to reduce malnutrition and nutrition insecurity in infants and children.

Blend of cereals, legumes and tubers in the formulation of composite flour can improve functional properties, nutrient contents and sensorial attributes. Therefore, the objective of this study was to develop nutrient dense finger millet based composite flour and products using soybean, ground nut and sweet potato mixes for injera, porridge and kitta product making.

\section{Materials and Methods}

\subsection{Sample Collection and Preparation}

Finger millet (Tadesse) variety which is widely cultivated by local surrounding farmers was obtained from Melkassa Agricultural Research Center. Soybean (Belessa-95) and orange fleshed sweet potato were collected from Pawe and Hawassa Agricultural Research Centers, respectively. Groundnut was purchased from a nearby local market. The collected samples were subjected to manual cleaning operation to remove extraneous matter and damaged grains, where it's necessary. The grain of finger millet was washed, sun dried and decorticated using hand pounding pestle for 5 min and then grinded using laboratory milling machine and kept in clean air tight polyethylene bag for blending and analysis. The cleaned soya bean grain was soaked in 1:3 $(\mathrm{w} / \mathrm{v})$ ratio by using tap water in medium size of plastic container for $12 \mathrm{hr}$ at room temperature. Soaked soya bean was washed using tap water and the excess water was drained. Then it was boiled for $2 \mathrm{hr}$ at $100^{\circ} \mathrm{C}$, the husk was separated and washed. The washed and dehulled soya beans grain was sun dried and milled to fine flour using laboratory milling machine and the obtained soya flour was kept in clean air tight polyethylene bag for analysis and blending. Ground nut grain was cleaned, roasted and the husk was removed, after that milled to fine flour and kept in clean air tight polyethylene bag for formulation. The raw roots of sweet potato was washed in tap water to remove dirt and soil, peeled and sliced into pieces, dried using lyophilizer, and then milled to fine flour using laboratory milling machine.

\subsection{Composite Flour Formulation}

Two types of composite flours were prepared, type I and II. Type I is formulated for injera, and type II for porridge and kitta making (Table 1). The formulated composite flour then mixed thoroughly with homogenizer into smooth homogenous powder and stored in airtight containers at room temperature $\left(25-30^{\circ} \mathrm{C}\right)$ until used.

Table 1. Ingredient formulation ratios.

\begin{tabular}{lllll}
\hline \multirow{2}{*}{$\begin{array}{l}\text { Composite } \\
\text { flour }\end{array}$} & \multicolumn{4}{l}{ Ingredients in percentage (\%) } \\
\cline { 2 - 5 } Control & Finger millet & Soya bean & Ground nut & Sweet potato \\
\hline & 65 & 0 & 0 & 0 \\
& 70 & 35 & 0 & 0 \\
Type I & 75 & 30 & 0 & 0 \\
& 80 & 25 & 0 & 0 \\
& 85 & 20 & 0 & 0 \\
& 60 & 15 & 0 & 0 \\
Type II & 70 & 20 & 20 & 0 \\
& 60 & 20 & 10 & 0 \\
& 70 & 20 & 0 & 20 \\
\hline
\end{tabular}

\subsection{Proximate Composition Determination}

Proximate compositions were determined following standard methods. Moisture content, fat content, protein content, ash content and crude fiber were determined by AOAC, [4] official method. Utilizable carbohydrate was determined using formula described below. Utilizable carbohydrate $(\%)=100-$ [protein $(\%)+$ crude fat $(\%)+$ crude fiber $(\%)+$ ash $(\%)+$ moisture $(\%)]$. The energy value was calculated using the Atwater and Benedict coefficients according to the following formula: Energy (Kcal/100 g) $=\%$ Utilizable carbohydrates $\times 4(\mathrm{Kcal})+\%$ proteins $\times 4(\mathrm{Kcal})$ $+\%$ fat $\times 9$ (Kcal) [3]. 


\subsection{Flour Functional Properties Characterization}

Swelling power, solubility, water absorption capacity and oil absorption capacity were evaluated to determine composting effect of finger millet flour with the legumes and orange fleshed sweet potato. Swelling power and solubility of the composite flour and ingredients were determined according to method described by, [29]. Flour samples of 0.4 $\mathrm{g}$ (dry basis, $\mathrm{db}$ ) were mixed with $12.5 \mathrm{ml}$ of water, heated at $80^{\circ} \mathrm{C}$ in thermo statically water bath for $5 \mathrm{~min}$ and after cooled, centrifuged at $5000 \mathrm{rpm}$ for $15 \mathrm{~min}$. The swelling volume was then calculated by converting the height of the resultant gels to a volume basis, and the results reported as $\mathrm{g} / \mathrm{g}$ of dry flour. The supernatant was carefully removed and the difference of the initial and final volume due to swelling was observed for measuring solubility and expressed per gram of the initial weight of the dry flour. Water and oil absorption capacity were determined using standard methods [17]. All experiments were repeated three times and values presented as the mean of the three observations.

\subsection{Injera Processing}

Injera was prepared using a standardized injera making procedure [37]. The procedure involved milling whole millet grain into a flour, preparation of a dough, and fermentation of the dough after adding yeast (a batter from a previous batch) and fermenting at room temperature for $48 \mathrm{hr}$. After fermentation, $80 \mathrm{~g}$ of the fermented dough was thinned with $30 \mathrm{~mL}$ of water and cooked in $200 \mathrm{ml}$ of boiling water for 1 min. The gelatinized batter was cooled to $45^{\circ} \mathrm{C}$ at room temperature and added back to the fermenting dough. After thorough mixing, $100 \mathrm{ml}$ of water was added and the batter was fermented at room temperature for $3 \mathrm{hr}$. Additional water $(20 \mathrm{ml})$ was added to the fermented dough to bring to batter consistency. About $500 \mathrm{~g}$ of the fermented batter was poured in a circular manner on a $50 \mathrm{~cm}$ diameter hot clay griddle, covered, and baked for $2 \mathrm{~min}$.

\subsection{Porridge Preparation}

Porridge was prepared using traditional method by adding $250 \mathrm{~g}$ of composite flour in $400 \mathrm{ml}$ of cold water before adding to $450 \mathrm{ml}$ of boiling water. The mixture was brought to boil under continuous stirring, then left to cooked for additional $15 \mathrm{~min}$.

\subsection{Kita Preparation}

Kita was prepared by kneading $250 \mathrm{~g}$ of composite flour in $150 \mathrm{ml}$ of water and baked on a heated mitad following the home made traditional baking process.

\subsection{Sensory Evaluation}

Consumer acceptability of developed injera, porridge and kita were evaluated using semi trained panelists based on five point hedonic scale $(1=$ dislike very much, $5=$ like very much). Thoroughly, 15 semi-trained panelists, consisting of men and women who regularly consume those foods were selected. The panelists were provided with the randomly sequenced baked/cooked product samples presented on the tray after cooled to room temperature. Selected attributes for injera evaluation were color, texture, aroma, taste, eye evenness, rollability, underneath color and overall rate. Porridge was evaluated for its mouth feel, aroma, color, taste and overall acceptability. Panelists evaluated the sensory acceptability of kita based on its texture, aroma, color, taste, appearance and overall acceptability.

\subsection{Data Analysis}

One-way ANOVA analysis of variance was used for statistical analysis. Generalized linear model (GLM) procedure for least square means and Duncan's Multiple Range Test (DMRT) for significant difference between means were used.

\section{Results and Discussions}

\subsection{Proximate Composition}

The results of proximate composition for composite flour are shown in Table 2. It was found that moisture content of the composite flour was significantly $(\mathrm{P}<0.05)$ varied among each other. It ranged from $8.14 \%$ to $10.06 \%$ for both types composite flour with the highest moisture content $(10.06 \%)$ recorded for composite flour formulated from $85 \%$ finger millet and $15 \%$ soyabean flour and the lowest moisture content $(8.14 \%)$ recorded for composite flour produced from $60 \%$ finger millet, $20 \%$ soyabean and $20 \%$ groundnut flour. Low moisture content in food samples increases the shelf life of food products through inhibition of microbial growth and biochemical reaction [2]. Ash value refers the amount of total mineral present in a given food sample. The higher ash value in the food sample is an indication of high mineral content. Statistically, the highest and lowest ash value were recorded for composite flour consisting of 70:30, finger millet and soybean flour and 70:20:10, finger millet, soybean, ground nut flour, respectively. Total ash content obtained in the current study was closely related to ash value reported for malted sorghum and soya bean based composite flour [7].

Protein is an essential parts of nutrients needed for growth and survival of both humans and animals. Protein content of the composite flour increased significantly as soya bean and ground nut proportion increased in the formulation (Table 2). The protein content range obtained in the current study $(4.37$ to $17.16 \%$ ) is in consistent with the protein content (7.3 to $19.2 \%$ ) of malted sorghum, soya bean and wheat based composite flour [8]. Soya beans have been reported to be a significant source of protein [30]. Several authors reported that Bambara ground nut also has substantially high protein content [35]. Increment of protein content with level of Bambara ground nut was also reported for extruded food products produced from different proportions of sorghum and bambara groundnut composite flour [16]. 
Table 2. Proximate composition of composite flours.

\begin{tabular}{llllllllllll}
\hline \multirow{2}{*}{ Trt } & \multicolumn{2}{l}{ Ingredients in percentage } & \multicolumn{2}{l}{ Proximate composition } \\
\cline { 2 - 15 } & FM & SB & GN & SP & Moisture (\%) & Ash (\%) & Fiber (\%) & Protein (\%) & Fat (\%) & Utilizable CHO (\%) & Energy (Kcal/100g) \\
\hline 0 & 100 & 0 & 0 & 0 & $10.48 \pm 0.66^{\mathrm{a}}$ & $2.23 \pm 0.83^{\mathrm{b}}$ & $8.50 \pm 0.24^{\mathrm{b}}$ & $7.20 \pm 0.69^{\mathrm{e}}$ & $0.02 \pm 0.25^{\mathrm{e}}$ & $71.57 \pm 0.39^{\mathrm{a}}$ & $315.26 \pm 3.28^{\mathrm{d}}$ \\
1 & 65 & 35 & 0 & 0 & $8.82 \pm 0.18^{\mathrm{c}}$ & $2.59 \pm 0.53^{\mathrm{b}}$ & $5.58 \pm 0.66^{\mathrm{c}}$ & $17.16 \pm 0.50^{\mathrm{a}}$ & $0.03 \pm 5.77^{\mathrm{e}}$ & $65.8 \pm 0.34^{\mathrm{c}}$ & $332.17 \pm 1.49^{\mathrm{d}}$ \\
2 & 70 & 30 & 0 & 0 & $8.78 \pm 0.12^{\mathrm{c}}$ & $3.17 \pm 0.040^{\mathrm{a}}$ & $7.07 \pm 1.57^{\mathrm{b}}$ & $15.09 \pm 0.07^{\mathrm{b}}$ & $0.04 \pm 0.01^{\mathrm{e}}$ & $65.84 \pm 1.30^{\mathrm{c}}$ & $324.09 \pm 6.22^{\mathrm{d}}$ \\
3 & 75 & 25 & 0 & 0 & $8.94 \pm 0.35^{\mathrm{bc}}$ & $2.82 \pm 0.03^{\mathrm{ab}}$ & $13.33 \pm 1.59^{\mathrm{a}}$ & $13.92 \pm 0.46^{\mathrm{c}}$ & $0.04 \pm 0.01^{\mathrm{e}}$ & $60.41 \pm 1.31^{\mathrm{e}}$ & $297.67 \pm 5.11^{\mathrm{f}}$ \\
4 & 80 & 20 & 0 & 0 & $9.36 \pm 0.34^{\mathrm{a}}$ & $2.85 \pm 0.01^{\mathrm{ab}}$ & $13.37 \pm 0.83^{\mathrm{a}}$ & $12.06 \pm 0.33^{\mathrm{d}}$ & $0.04 \pm 0.02^{\mathrm{e}}$ & $63.32 \pm 0.84^{\mathrm{d}}$ & $301.86 \pm 1.95^{\mathrm{e}}$ \\
5 & 85 & 15 & 0 & 0 & $10.06 \pm 0.20^{\mathrm{a}}$ & $2.79 \pm 0.16^{\mathrm{ab}}$ & $13.43 \pm 0.29^{\mathrm{a}}$ & $11.93 \pm 0.57^{\mathrm{d}}$ & $0.17 \pm 0.13^{\mathrm{d}}$ & $61.99 \pm 0.77^{\mathrm{e}}$ & $297.00 \pm 2.35^{\mathrm{f}}$ \\
6 & 60 & 20 & 20 & 0 & $8.14 \pm 0.86^{\mathrm{b}}$ & $1.02 \pm 1.52^{\mathrm{c}}$ & $4.11 \pm 0.72^{\mathrm{d}}$ & $4.37 \pm 1.00^{\mathrm{g}}$ & $15.58 \pm 2.02^{\mathrm{a}}$ & $67.76 \pm 0.37^{\mathrm{b}}$ & $428.8 \pm 15.23^{\mathrm{a}}$ \\
7 & 70 & 20 & 10 & 0 & $9.61 \pm 1.42^{\mathrm{a}}$ & $1.028 \pm 4.58^{\mathrm{c}}$ & $2.85 \pm 0.52^{\mathrm{cd}}$ & $7.62 \pm 0.98^{\mathrm{e}}$ & $11.17 \pm 0.18^{\mathrm{b}}$ & $68.71 \pm 1.37^{\mathrm{a}}$ & $405.88 \pm 6.68^{\mathrm{b}}$ \\
8 & 60 & 20 & 0 & 20 & $9.342 \pm 0.92^{\mathrm{a}}$ & $1.028 \pm 0.01^{\mathrm{c}}$ & $5.92 \pm 9.45^{\mathrm{c}}$ & $9.96 \pm 0.03^{\mathrm{f}}$ & $6.57 \pm 0.09^{\mathrm{c}}$ & $68.16 \pm 0.89^{\mathrm{ab}}$ & $371.71 \pm 3.86^{\mathrm{c}}$ \\
9 & 70 & 20 & 0 & 10 & $8.679 \pm 0.58^{\mathrm{c}}$ & $1.036 \pm 0.01^{\mathrm{c}}$ & $4.03 \pm 0.68^{\mathrm{d}}$ & $13.99 \pm 0.96^{\mathrm{c}}$ & $6.72 \pm 0.2^{\mathrm{c}}$ & $66.54 \pm 1.66^{\mathrm{b}}$ & $382.63 \pm 6.07^{\mathrm{c}}$ \\
\hline
\end{tabular}

Where, $\mathrm{FM}=$ Finger millet, $\mathrm{SB}=$ Soyabean, $\mathrm{GN}=$ Ground nut, $\mathrm{SP}=$ Sweet potato, Trt =Treatment, Values are mean \pm standard deviation Mean values with the same letter of superscripts are not significantly different $(\mathrm{P}>0.05)$

Cereal, tubers and legume are known for their good source of fiber. However, the level of fiber in each category is highly varied. The crude fibre of the composite flour in this work was ranged from 2.85 to $13.86 \%$ and there was a significant variation among composite flours. The crude fiber content range of 5.58 to $13.86 \%$, and 2.85 to $5.92 \%$ was observed for composite flour I and II, respectively. An increment in fiber content was noticed as the proportion of finger millet increased. The crude fiber content of composite flour in the present study was remarkably higher than fiber content (1.64 $-1.79 \%$ ) reported for four weaning foods made up of finger millet, peanut, green gram and skimmed milk powder [21]. The highest percentage of crude fat was observed with type II composite flours and ranged from 6.57 to $15.58 \%$. Crude fat content of composite flour in the present study increased as soyabean and ground nut supplementation level increased. This could be due to the presence of appreciable amount of fat in both soyabean and groundnut. The related research finding indicated that the fat content of rice and soyabean composite flour increased as soy flour proportion increased [11].

The highest utilizable carbohydrate content $(71.57 \%)$ in this study was recorded for $100 \%$ finger millet flour while the lowest $(60.41 \%)$ was noted for composite flour composed of $75 \%$ finger millet and $25 \%$ soyabean flour. This indicate that utilizable carbohydrate content of the finger millet based composite flour in this study might not improve with soyabean, ground nut and sweet potato incorporation. The obtained utilizable carbohydrate content (60.41-68.71\%) in this study was in line with carbohydrate content $(65.95 \%)$ reported for complementary food produced from 50:15:35 of sweet potato, finger rmillet and soyabean flour, respectively [9].

Energy value exhibited significant difference $(\mathrm{P}<0.05)$ for developed composite flour in the present study. Accordingly, the highest energy value $(428.83 \mathrm{Kcal} / 100 \mathrm{~g})$ in this study was recorded for $3: 1: 1$ of finger millet, soyabean and groundnut flour, respectively, whereas the lowest (297.67 $\mathrm{Kcal} / 100 \mathrm{~g}$ ) energy value was obtained from composite flour composed of $75 \%$ finger millet and $25 \%$ soyabean flour. The highest energy value recorded could be attributed by high protein and fat contribution from soyabean and ground nut flour.

The energy value recorded in the present study was lower than energy value $(340-398 \mathrm{kcal} / 100 \mathrm{~g})$ reported for eight composite mix composed of cereals (finger millet, pearl millet or sorghum, wheat), legumes (defatted soya flour, bengal gram dhal) jaggery and vegetable fat [5]. On the other hand, the energy value of composite flour formulated from finger millet, soyabean, ground nut, and sweet potato in the present study was higher than energy value (357- 374 $\mathrm{kcal} / 100 \mathrm{~g}$ ) reported for formulated mix having 70:30:25 ratio of cereals, green gram and jaggery [14]. This might be due to significant variation of protein, fat and carbohydrate contribution for energy from individual components used for ingredient formulation.

\subsection{Functional Properties}

The results of functional properties of composite flour are presented in Table 3. Water solubility index (WSI) reflects the presence of soluble molecules and is a measure of starch degradation. Statistically significant $(\mathrm{P}<0.05)$ difference was observed among water solubility of finger millet and soya bean composite flour. WSI of the composite flours was varied from 11.64 to $13.17 \mathrm{~g} / \mathrm{g}$. The WSI values observed in this study were slightly higher than water solubility recorded in multigrain (millets, rice, wheat, chickpea and soyabean) composite flour [31]. Swelling power is regarded as quality criterion in some good formulations such as bakery products. The swelling power is an indication of presence of amylase which influences the quantity of amylose and amylopectin present in the flour. Swelling power is also related to the water absorption index of the starch-based flour during heating [23]. The higher the swelling power, the higher the associate forces. The swelling power of the composite flours ranged from $120.36-145.83 \%$, and there was not significance difference between formulated composite flours $(\mathrm{P}>0.05)$.

The Water Absorption Capacity (WAC) measures the volume occupied by the starch after swelling in excess water, which maintains the integrity of starch in aqueous dispersion. The WAC is important in the development of ready to eat foods, and a high absorption capacity may assure product cohesiveness [19]. Results showed that highest WAC (21.58 $\mathrm{g} / \mathrm{g}$ ) was observed in composite flour formulated from $70 \%$ 
finger millet, $20 \%$ soya bean and $10 \%$ sweet potato, and the lowest $(12.34 \mathrm{~g} / \mathrm{g})$ observed in composite flour formulated from $75 \%$ of finger millet and $25 \%$ of soya bean flour. Oil absorption capacity (OAC) measures the ability of the flour protein to physically bind fat by capillary attraction. Oil absorption capacity values ranged from $100 \mathrm{~g} / \mathrm{g}$ to $150 \mathrm{~g} / \mathrm{g}$. The results of Oil absorption capacity of composite flour obtained in the present study was higher than the OAC reported for lima bean, sorghum and wheat composite flour [1].

Table 3. Functional properties of composite flours.

\begin{tabular}{|c|c|c|c|c|c|c|c|c|c|}
\hline \multirow{2}{*}{$\begin{array}{l}\text { Composite } \\
\text { flour }\end{array}$} & \multirow{2}{*}{ Trt } & \multicolumn{4}{|c|}{ Ingredients in percentage } & \multicolumn{4}{|c|}{ Functional properties } \\
\hline & & Finger millet & Soya bean & Groundnut & Sweet potato & Swelling power & solubility & OAC & WAC \\
\hline \multirow[t]{3}{*}{ Control } & 0 & 100 & 0 & 0 & 0 & $123.21 \pm 1.57^{\mathrm{a}}$ & $11.91 \pm 0.13^{\mathrm{a}}$ & $151 \pm 1.33^{\mathrm{a}}$ & $18.01 \pm 0.52^{\mathrm{a}}$ \\
\hline & 1 & 65 & 35 & 0 & 0 & $119.29 \pm 2.52^{\mathrm{a}}$ & $11.64 \pm 0.40^{\mathrm{b}}$ & $125 \pm 2.5^{\mathrm{ab}}$ & $17.63 \pm 0.33^{\mathrm{a}}$ \\
\hline & 2 & 70 & 30 & 0 & 0 & $119.93 \pm 0.63^{\mathrm{a}}$ & $11.96 \pm 0.32^{\mathrm{ab}}$ & $137.5 \pm 1^{\mathrm{a}}$ & $15.31 \pm 2.31^{\mathrm{ab}}$ \\
\hline \multirow[t]{3}{*}{ Type I } & 3 & 75 & 25 & 0 & 0 & $120.08 \pm 0.15^{\mathrm{a}}$ & $11.75 \pm 0.17^{\mathrm{a}}$ & $150 \pm 0.0^{\mathrm{a}}$ & $12.34 \pm 0.22^{\mathrm{b}}$ \\
\hline & 4 & 80 & 20 & 0 & 0 & $120.12 \pm 0.03^{\mathrm{a}}$ & $11.87 \pm 0.08^{\mathrm{a}}$ & $100 \pm 50.0^{\mathrm{b}}$ & $17.52 \pm 0.35^{\mathrm{a}}$ \\
\hline & 5 & 85 & 15 & 0 & 0 & $120.13 \pm 1.0^{\mathrm{a}}$ & $11.90 \pm 0.02^{\mathrm{a}}$ & $100 \pm 0.0^{\mathrm{b}}$ & $18.06 \pm 0.53^{\mathrm{b}}$ \\
\hline \multirow{3}{*}{ Type II } & 7 & 70 & 20 & 10 & 0 & $120.14 \pm 5.77^{\mathrm{a}}$ & $13.17 \pm 0.28^{\mathrm{a}}$ & $100 \pm 0.0^{\mathrm{a}}$ & $18.18 \pm 0.19^{b}$ \\
\hline & 8 & 60 & 20 & 0 & 20 & $120.14 \pm 0.0^{\mathrm{a}}$ & $12.66 \pm 0.51^{\mathrm{ab}}$ & $100 \pm 0.0^{\mathrm{a}}$ & $19.34 \pm 1.16^{\mathrm{ab}}$ \\
\hline & 9 & 70 & 20 & 0 & 10 & $120.14 \pm 0.0^{\mathrm{a}}$ & $12.42 \pm 0.09^{\mathrm{ab}}$ & $100 \pm 0.0^{\mathrm{a}}$ & $21.58 \pm 0.35^{\mathrm{a}}$ \\
\hline
\end{tabular}

Note: $\operatorname{Trt}=$ Treatments, $\mathrm{OAC}=$ Oil absorption capacity, WAC $=$ Water absorption capacity

\subsection{Sensory Evaluation}

The sensory characteristic of finger millet based valueadded injera is presented in Table 4 . A significant $(\mathrm{p}<0.05)$ variation was observed between formulations in their color, texture, flavor, taste, eye distribution, underneath color, rollability and overall acceptance. Among formulations, injera made from $70 \% \mathrm{FM}+30 \% \mathrm{SB}$ was perceived differently and rated higher in its color and taste. The most acceptable texture, flavor, underneath color and rollability were noticed with $75 \% \mathrm{FM}+25 \% \mathrm{SB}$. Obviously injera with a characteristics of white color, even eye distribution, less sourness and bitterness, rollable and less stick is preferred by consumers [15]. It was observed that numerous and even distribution of eyes were formed with injera prepared from $65 \% \mathrm{FM}+35 \% \mathrm{SB}$ formulation Injera eye is a honeycomb like structure of the top surface of the product and it's formed during baking/cooking due to escaping of $\mathrm{CO}_{2}$ bubbles [36] A number of Research finding revealed that as the temperature of the tef batter rises during baking, the carbon dioxide in the batter comes out of solution and at the same time, the starch in the batter gelatinizes increasing the viscosity of the batter [34]. This creates gas bubbles in the batter that turn into cells as the gas escapes and the batter sets. Pyle (2005) stated that the small bubbles of $\mathrm{CO}_{2}$ resulting from fermentation play a crucial role as nuclei for pore development and without these nuclei a porous structure in the final product may not be formed. According to this author, the $\mathrm{CO}_{2}$ nuclei formed during primary fermentation could possibly be the main determinant of the number of eyes that will be formed on the surface of injera.

Table 4. Sensory results of injera prepared from finger millet and soybean composite flour.

\begin{tabular}{|c|c|c|c|c|c|c|c|c|}
\hline Formulations & Color & Texture & Aroma & Taste & Eye evenness & Underneath color & Rollability & Overall acceptance \\
\hline $100 \% \mathrm{FM}$ & $4.13 \pm 0.23^{\mathrm{a}}$ & $4.13 \pm 0.46^{\mathrm{ab}}$ & $4.13 \pm 0.31^{\mathrm{a}}$ & $3.87 \pm 0.11^{\mathrm{ab}}$ & $4.13 \pm 0.12^{\mathrm{ab}}$ & $3.96 \pm 0.17^{\mathrm{ab}}$ & $3.92 \pm 0.19^{\mathrm{ab}}$ & $4.0 \pm 0.13^{\mathrm{a}}$ \\
\hline $65 \% \mathrm{FM}+35 \% \mathrm{SB}$ & $3.60 \pm 0.20^{\mathrm{b}}$ & $3.60 \pm 0.35^{\mathrm{ab}}$ & $3.53 \pm 0.31^{\mathrm{b}}$ & $4.0 \pm 0.34^{\mathrm{ab}}$ & $4.47 \pm 0.12^{\mathrm{a}}$ & $3.84 \pm 0.0^{\mathrm{ab}}$ & $3.89 \pm 3.89^{\mathrm{ab}}$ & $3.94 \pm 0.04^{\mathrm{ab}}$ \\
\hline $70 \% \mathrm{FM}+30 \% \mathrm{SB}$ & $4.27 \pm 0.31^{\mathrm{a}}$ & $3.67 \pm 0.23^{\mathrm{ab}}$ & $3.80 \pm 0.53^{\mathrm{ab}}$ & $4.07 \pm 0.11^{\mathrm{a}}$ & $3.93 \pm 0.31^{\mathrm{b}}$ & $3.95 \pm 0.08^{\mathrm{ab}}$ & $3.88 \pm 0.14^{\mathrm{ab}}$ & $3.93 \pm 0.18^{\mathrm{ab}}$ \\
\hline $75 \% \mathrm{FM}+25 \% \mathrm{SB}$ & $3.87 \pm 0.23^{\mathrm{ab}}$ & $4.0 \pm 0.00^{\mathrm{a}}$ & $4.33 \pm 0.23^{\mathrm{a}}$ & $3.60 \pm 0.40^{\mathrm{b}}$ & $4.20 \pm 0.20^{\mathrm{ab}}$ & $4.0 \pm 0.11^{\mathrm{a}}$ & $4.03 \pm 0.08^{\mathrm{a}}$ & $4.03 \pm 0.09^{\mathrm{a}}$ \\
\hline $80 \% \mathrm{FM}+20 \% \mathrm{SB}$ & $4.25 \pm 0.19^{\mathrm{a}}$ & $3.65 \pm 0.25^{\mathrm{ab}}$ & $3.60 \pm 0.16^{\mathrm{b}}$ & $3.70 \pm 0.11^{\mathrm{ab}}$ & $4.15 \pm 0.44^{\mathrm{ab}}$ & $3.87 \pm 0.06^{\mathrm{ab}}$ & $3.79 \pm 0.05^{\mathrm{b}}$ & $3.82 \pm 0.07^{\mathrm{b}}$ \\
\hline $85 \% \mathrm{FM}+15 \% \mathrm{SB}$ & $3.90 \pm 0.14^{\mathrm{ab}}$ & $3.40 \pm 0.28^{\mathrm{b}}$ & $3.80 \pm 0.00^{\mathrm{ab}}$ & $3.80 \pm 0.00^{\mathrm{ab}}$ & $4.10 \pm 0.14^{\mathrm{ab}}$ & $3.80 \pm 0.06^{\mathrm{b}}$ & $3.78 \pm 0.09^{\mathrm{b}}$ & $3.86 \pm 0.06^{\mathrm{ab}}$ \\
\hline
\end{tabular}

a and $b$ superscripts are significantly $(\mathrm{p}<0.05)$ different column wise among different formulations, FM, finger millet; SB, soybean

Rollability is one of the most important injera sensory attribute as it describes the ability of injera being rolled without breaking. The result showed that formulations $75 \% \mathrm{FM}+25 \% \mathrm{SB}$ and $80 \% \mathrm{FM}+20 \% \mathrm{SB}$ had the highest and the lowest rollability with a significant difference among them. This difference could be due to realignment of amylose and amylopectin compositions of starch which might affect the textural and nutritional attributes of injera.

Porridge is also another product which can be made from cereals and it's a food commonly eaten as a breakfast. The sensory results of porridge from the four formulations are shown in Table 5. The results ranged from 3.07 to 4 for aroma and overall acceptance, 2.87 to 3.87 for color, 2.93 to 3.6 for mouth feel, and 3.2 to 4 for taste. No significant ( $p>0.05$ ) difference were observed in color, mouth feel and taste of the porridge products. However, the formulations $60 \% \mathrm{FM}+20 \% \mathrm{SB}+20 \% \mathrm{SP}$ and $70 \% \mathrm{FM}+20 \% \mathrm{SB}+10 \% \mathrm{GN}$ were rated higher and lower in their mouth feel and taste, respectively. Formulation $60 \% \mathrm{FM}+20 \% \mathrm{SB}+20 \% \mathrm{SP}$ perceived highest in its aroma and overall acceptance, while $70 \% \mathrm{FM}+20 \% \mathrm{SB}+10 \% \mathrm{GN}$ perceived the lowest. 
Table 5. Sensory results of finger millet based porridge.

\begin{tabular}{llllll}
\hline Formulations & Aroma & Color & Mouth feel & Taste & Overall acceptance \\
\hline $60 \% \mathrm{FM}+20 \% \mathrm{SB}+20 \% \mathrm{GN}$ & $3.47 \pm 0.31^{\mathrm{ab}}$ & $2.87 \pm 0.42^{\mathrm{a}}$ & $3 \pm 0.48^{\mathrm{a}}$ & $3.2 \pm 0.20^{\mathrm{a}}$ & $3.47 \pm 0.31^{\mathrm{ab}}$ \\
$70 \% \mathrm{FM}+20 \% \mathrm{SB}+10 \% \mathrm{GN}$ & $3.07 \pm 0.50^{\mathrm{b}}$ & $2.87 \pm 0.81^{\mathrm{a}}$ & $2.93 \pm 0.83^{\mathrm{a}}$ & $3.2 \pm 0.60^{\mathrm{a}}$ & $3.07 \pm 0.50^{\mathrm{b}}$ \\
$60 \% \mathrm{FM}+20 \% \mathrm{SB}+20 \% \mathrm{SP}$ & $4.00 \pm 0.60^{\mathrm{a}}$ & $3.87 \pm 0.57^{\mathrm{a}}$ & $3.60 \pm 0.69^{\mathrm{a}}$ & $4.00 \pm 0.28^{\mathrm{a}}$ & $4.00 \pm 0.60^{\mathrm{a}}$ \\
$70 \% \mathrm{FM}+20 \% \mathrm{SB}+10 \% \mathrm{SP}$ & $3.47 \pm 0.31^{\mathrm{ab}}$ & $3.47 \pm 0.50^{\mathrm{a}}$ & $3.4 \pm 0.52^{\mathrm{a}}$ & $3.33 \pm 0.05^{\mathrm{a}}$ & $3.47 \pm 0.31^{\mathrm{ab}}$ \\
\hline
\end{tabular}

a and $\mathrm{b}$ superscripts are significantly $(\mathrm{p}<0.05)$ different in a column. FM, finger millet; SB, soybean; SP, sweet potato

Table 6 illustrates the sensory characteristics of kita products prepared from different proportions of finger millet, soybean, ground nut and sweet potato. The color, texture, aroma, taste, appearance and over all acceptability results indicated that there was not a significant difference between the formulations $(\mathrm{P}>0.05)$. Formulation $70 \% \mathrm{FM}+20 \% \mathrm{SB}+$
$10 \% \mathrm{SP}$ perceived utmost and scored highest in its color, texture, taste, appearance and overall acceptance, whereas $70 \% \mathrm{FM}+20 \% \mathrm{SB}+10 \% \mathrm{GN}$ formulation rated lowest. An increased in sweet potato and ground nut proportions resulted in lower consumer acceptability.

Table 6. Sensory characteristics of finger millet based kita.

\begin{tabular}{|c|c|c|c|c|c|c|}
\hline Formulations & Color & Texture & Aroma & Taste & Appearance & Overall acceptance \\
\hline $60 \% \mathrm{FM}+20 \% \mathrm{SB}+20 \% \mathrm{GN}$ & $3.67 \pm 0.31^{\mathrm{ab}}$ & $3.53 \pm 0.50^{\mathrm{a}}$ & $3.47 \pm 0.76^{\mathrm{a}}$ & $3.35 \pm 1.19^{\mathrm{a}}$ & $3.27 \pm 0.64^{\mathrm{a}}$ & $3.8 \pm 0.60^{\mathrm{a}}$ \\
\hline $70 \% \mathrm{FM}+20 \% \mathrm{SB}+10 \% \mathrm{GN}$ & $3.13 \pm 0.31^{\mathrm{b}}$ & $3.27 \pm 0.61^{\mathrm{a}}$ & $3.07 \pm 0.41^{\mathrm{a}}$ & $3.23 \pm 0.68^{\mathrm{a}}$ & $2.80 \pm 0.80^{\mathrm{a}}$ & $3.53 \pm 0.50^{\mathrm{a}}$ \\
\hline $60 \% \mathrm{FM}+20 \% \mathrm{SB}+20 \% \mathrm{SP}$ & $3.80 \pm 0.52^{\mathrm{a}}$ & $3.47 \pm 0.61^{\mathrm{a}}$ & $3.67 \pm 0.50^{\mathrm{a}}$ & $3.32 \pm 0.43^{\mathrm{a}}$ & $3.4 \pm 0.34^{\mathrm{a}}$ & $3.73 \pm 0.23^{\mathrm{a}}$ \\
\hline $70 \% \mathrm{FM}+20 \% \mathrm{SB}+10 \% \mathrm{SP}$ & $3.93 \pm 0.50^{\mathrm{a}}$ & $3.8 \pm 0.20^{\mathrm{a}}$ & $3.33 \pm 0.23^{\mathrm{a}}$ & $3.44 \pm 0.31^{\mathrm{a}}$ & $3.53 \pm 0.31^{\mathrm{a}}$ & $3.80 \pm 0.34^{\mathrm{a}}$ \\
\hline
\end{tabular}

a and $b$ superscripts are significantly $(\mathrm{p}<0.05)$ different in a column. FM, finger millet; SB, soybean; SP, sweet potato

\section{Conclusion}

This study has shown that protein, fat and energy level of composite flour increased with increasing substitution level of soybean and ground nut. Crude fiber, ash and carbohydrate content of composite flour were increased as incorporation level of finger millet and sweet potato flour increased. Incorporation of sweet potato and ground nut flour have substantial role in partial improvement of some functional properties of the composite flour. Correspondingly, water solubility and water absorption capacity were increased as the substitution level of orange fleshed sweet potato and groundnut increased. Sensory attributes of injera made from composite flour consisting of finger millet and soyabean were in acceptable range upto $35 \%$ of soyabean incorporation level. In addition, this study reflected that acceptable, convenient nutrient dense and low cost complementary food products (kita and porridge) were produced from formulations contained higher finger millet, higher soybean and lower ground nut and sweet potatoes. Taste and texture attributes were the most influencing factors for kita and porridge preferences.

\section{Acknowledgements}

We are grateful to coordinator of the Alternative Food product development and popularization project supported by the Food science and nutrition research directorate of Ethiopian Institute of Agricultural Research for full financial sponsorship of this work. We also have special gratitude to Miss Mulu Daba, laboratory technician team of Food science and Nutrition research directorate for her cooperation, providing us with all the necessary materials and laboratory facilities.

\section{References}

[1] Adebayo, S. F., \& Okoli, E. C. (2017). Production and evaluation of biscuits from lima bean (Phaseolus Lunatus), sorghum and wheat flour blends. Journal of Environmental Science, Toxicology and Food Technology, 11 (7), 23192402.

[2] Alozie, Y. E., Iyam, M. A., Lawal, O., Udofia, U., \& Ani, I. F. (2009). Utilization of Bambara Groundnut Flour blends in bread production. Journal of Food Technology, 7 (4), 111-114.

[3] Atwater WO, Benedict FG. (1899). Experiments on the metabolism of matter and energy in the human body. US Dept Exper Stations Bulletin, Washington DC, USA, 69: 112.

[4] AOAC (2000). Association of Official AnalyticalChemists. 17th Edn., Official Method of Analysis, Washington D. C., USA.

[5] Bhaskaran, V., Mahadevamma Malleshi, N. G., Jayaprakashan, S. G. and Lokesh, B. R. (2001). Biological evaluation for protein quality of supplementary foods based on popped cereals and legumes suitable for feeding rural mothers and children in India. Plant Food Human Nutrition, 56: 37-49.

[6] BNF (British Nutrition Foundation) (2004). Nutritional aspects of cereals. London: BNF. Nutrition \& Food Science. https://doi.org/10.1108/nfs.2004.01734fab.017

[7] Bolarinwa, I. F., Abioye, A. O., Adeyanju, J. A., \& Kareem, Z. O. (2016). Production and quality evaluation of biscuits produced from malted sorghum-soy flour blends. Journal of Advances in Food Science \& Technology, 3 (3), 107-113.

[8] Bolarinwa, I. F., Olaniyan, S. A., Adebayo, L. O., \& Ademola, A. A. (2015). Malted sorghum-Soy composite flour: Preparation, chemical and physico-chemical properties. Journal of Food Processing \& Technology, 6 (8), 1. 
[9] Damian, L., Faustina, D., Wireko, M. 1 and Ibok, O. 2018. Formulation and characterization of sweetpotato-based complementary food. Cogent Food and Agriculture, 4: 1517426 .

[10] Desai, A. D., Kulkarni, S. S., Sahoo, A. K., Ranveer, R. C., \& Dandge, P. B. (2010). Effect of supplementation of malted ragi flour on the nutritional and sensorial quality characteristics of cake. Advance Journal of Food Science and Technology, 2 (1), 67-71.

[11] Falola, A. O., Olatidoye, O. P., Balogun, I. O. and Opeifa, A. O. (2013). Evaluation of nutritional, physicochemical properties and acceptability of un-dehulled 'ofada' rice and soy bean flour blends. Journal of Agriculture and Veterinary Science, 5: 118-128.

[12] FAO. (1995). Sorghum and millets in human nutrition. Food and Agriculrure Organization of the United Nations.

[13] Faruque, A. S. G., Ahmed, A. S., Ahmed, T., Islam, M. M., Hossain, M. I., Roy, S. K.,... \& Sack, D. A. (2008). Nutrition: basis for healthy children and mothers in Bangladesh. Journal of health, population, and nutrition, 26. (3), 325 .

[14] Gahlawat, P. and Sehgal, S. (1994). Protein quality of weaning foods based on locally available cereal and pulse combination. Plant Food Human Nutrition, 46: 245-253.

[15] Gebrekidan, B., GebreHiwot, B. (1982). Sorghum Injera Preparations and Quality Parameters, in: Rooney, L. W., Murty, D. (Eds.), International Symposium on Sorghum Grain Quality. J. V. Mertin, Patansheru, India, pp. 55-66.

[16] Gbenyi, D. I., Nkama, I., \& Badau, M. H. (2016). Optimization of physical and functional properties of sorghum-bambara groundnut extrudates. Journal of Food Research, 5 (2), 81-97.

[17] Hassan, H. A., Mustafa, A. I., \& Ahmed, A. R. (2013). Effect of incorporation of decorticated pigeon pea (Cajanus cajan) protein isolate on functional, baking and sensory characteristics of Wheat (Triticum aestivum) biscuit. Food Science and Technology. 5 (8), 976-981.

[18] Hasmadi, M., Matanjun, P., Salwa, I., Siti, F., Mansoor, A. H., \& Ainnur, S. R. (2014). The effect of seaweed composite flour on the textural properties of dough and bread. Journal of Applied Phycology, 26 (2), 1057-1062.

[19] Housson, P., Ayenor., G. S. (2002). Appropriate processing and food functional properties of maize flour. Afr. J. Sci. Technol. 3 (1): 126-121.

[20] Hugo, L. F., Rooney, L. W., \& Taylor, J. R. N. (2000). Malted sorghum as a functional ingredient in composite bread. Cereal chemistry, 77 (4), 428-432.

[21] Kshirsagar, R. B., Pawar, V. D., Upadhaye, V. P., Pawar, V. S. and Devi, R. (1994). Studies on formulation and evaluation of weaning food based on locally available foods. Journal of Food Science and Technology, 31 (3): 211-214.

[22] Kosambo, L. M., E. E. Carey, A. K. Misera, J. Wilkes and V. Hagenimana, 1998. Influence of age, farming site and boiling provitamin A contents in sweet potato (Ipomoea batatas (L) lam) storage roots. J. Food Comp. Analysis, 11: 305-321.
[23] Loss, P. J., Hood, L. F. and Graham, A. J. (1981). Isolation and characterization of starch from breadfruit. Cereal Chem., 58: 282-286.

[24] Mepba, H. D., Eboh, L., \& Nwaojigwa, S. U. (2007). Chemical composition, functional and baking properties of wheat-plantain composite flours. African Journal of food, agriculture, nutrition and development, 7 (1).

[25] Müller, O., \& Krawinkel, M. (2005). Malnutrition and health in developing countries. Cmaj, 173 (3), 279-286.

[26] Pyle, D. L. (2005). Crumpet structures-experimental and modelling studies. Food Bioprod. Process. 83, 81-88.

[27] Ramashia, S. E., Anyasi, T. A., Gwata, E. T., MeddowsTaylor, S., \& Jideani, A. I. O. (2019). Processing, nutritional composition and health benefits of finger millet in sub-saharan Africa. Food Science and Technology, 39 (2), 253-266.

[28] Ruel, M. T. (2001). Can food-based strategies help reduce vitamin A and iron deficiencies (No. 594-2016-39955).

[29] Schoch, T. J. (1964). Swelling power and solubility of granular starches." Methods in carbohydrate chemistry 4 106108.

[30] Serrem, C. A., de Kock, H. L., \& Taylor, J. R. (2011). Nutritional quality, sensory quality and consumer acceptability of sorghum and bread wheat biscuits fortified with defatted soy flour. International Journal of Food Science \& Technology, 46 (1), 74-83.

[31] Singh, P., \& Raghuvanshi, R. S. (2012). Finger millet for food and nutritional security. African Journal of Food Science, 6 (4), 77-84.

[32] Sudha, A., Priyenka Devi, K. S., Sangeetha, V., \& Sangeetha, A. (2016). Development of fermented millet sprout milk beverage based on physicochemical property studies and consumer acceptability data. Journal of Scientific and Industrial Research.

[33] Takhellambam, R. D., Chimmad, B. V., \& Prkasam, J. N. (2016). Ready-to-cook millet flakes based on minor millets for modern consumer. Journal of Food Science and Technology. https://doi.org/10.1007/s13197-015-2072-0

[34] Taylor, J. R., \& Emmambux, M. N. (2008). Gluten-free foods and beverages from millets. In Gluten-free cereal products and beverages (pp. 119-V). Academic Press.

[35] Uvere, P. O., Uwaegbute, A. C., \& Adedeji, E. M. (1999). Effects of malting on the milling performance and acceptability of bambara groundnut (Voandzeia subterranea Thouars) seeds and products. Plant Foods for Human Nutrition, 54 (1), 49-57.

[36] Yetneberk, S., Rooney, L. W., \& Taylor, J. R. (2005). Improving the quality of sorghum injera by decortication and compositing with tef. Journal of the Science of Food and Agriculture, 85 (8), 1252-1258.

[37] Yetneberk, S., De Kock, H. L., Rooney, L. W., \& Taylor, J. R. N. (2004). Effects of Sorghum Cultivar on Injera Quality. CerealChemistry. https://doi.org/10.1094/CCHEM.2004.81.3. 314. 